Putri, Purbasari, Handayani dan Ulynnuha / 2018

\title{
ANALISIS FAKTOR-FAKTOR YANG BERPENGARUH TERHADAP KESADARAN KEWAJIBAN PERPAJAKAN PADA SEKTOR USAHA KECIL DAN MENENGAH (UKM)
}

\author{
Eskasari Putri ${ }^{1}$ \\ * Fakultas Ekonomi dan Bisnis, Universitas Muhammadiyah Surakarta \\ *ep122@ums.ac.id ${ }^{1}$ \\ Heppy Purbasari ${ }^{2}$ \\ * Fakultas Ekonomi dan Bisnis, Uninversitas Muhammadiyah Surakarta \\ *heppy.purbasari@ums.ac.id ${ }^{2}$ \\ Meiga Trisna Handayani ${ }^{3}$ \\ * Fakultas Ekonomi dan Bisnis, Uninversitas Muhammadiyah Surakarta \\ *meigatrisnahandayani@gmail.com ${ }^{3}$ \\ Ovi Itsnaini Ulynnuha ${ }^{4}$ \\ * Fakultas Ekonomi dan Bisnis, Uninversitas Muhammadiyah Surakarta
}

\begin{abstract}
This study aims to examine the influence of taxpayer knowledge, understanding of self assessment system, taxpayer income level and easiness in performing tax payment system to awareness of taxation obligation on small and medium business sector. The sample in this research are 44 respondents who are owners of small and medium enterprises located in Central Java region. The results in this study were collected through questionnaires that were processed and analyzed by using multiple regression analysis. The method used in determining the sample in this study is Convenience Sampling. The data quality test used in this research is Pearson Correlation validity test and reliability test using Cronbach Alpha. To test the hypothesis in this study, this study uses adjusted R2 test, F test, and $t$ test. The results of this research data indicate that the knowledge of taxpayers, understanding the self assessment system, and the income level of the taxpayer does not affect the awareness of tax obligations. While the easiness variable in performing tax payment system affect the awareness of tax obligation.
\end{abstract}

Keywords: Knowledge of taxpayer, understanding of self assessment system, income taxpayer level, easiness in performing tax payment system, awareness of taxation obligation.

\section{Pendahuluan}

Sumber penerimaan negara terbesar berasal dari pajak. Pajak memiliki peran yang sangat besar dan semakin diandalkan untuk kepentingan pembangunan nasional dan pengeluaran negara. Pentingnya kontribusi pajak dalam pembangunan nasional dan pengeluaran negara, harus diimbangi dengan tanggung jawab masyarakat agar pembangunan dapat berjalan dengan lancar. Dana yang dikeluarkan dalam upaya melakukan pembangunan nasional ini akan semakin meningkat seiring dengan kebutuhan pembangunan itu sendiri. Hal ini dapat teratasi apabila pajak yang diterima oleh negara juga besar.

Kesadaran wajib pajak merupakan salah satu faktor penentu dalam lancarnya pembangunan nasional. Munculnya kesadaran dari para wajib pajak, akan memengaruhi proses pembangunan nasional. Saat ini, masih banyak ketidaktaatan dalam membayar pajak yang tidak hanya terjadi pada lapisan pengusaha saja tetapi juga terjadi pada pekerja professional. Sedangkan untuk saat ini, perkembangan unit usaha di Indonesia dapat dikatakan meningkat.

Pertumbuhan jumlah usaha terutama Usaha Mikro, Kecil, dan Menengah (UMKM) di Indonesia yang senantiasa meningkat. UMKM di Indonesia mengalami perkembangan sebesar 1,9 juta unit selama tahun 2014-2015 (www.bps.go.id). Banyaknya jumlah unit UMKM di Indonesia seharusnya juga tercermin pada penerimaan pajak. Namun penerimaan pajak didominasi oleh Wajib Pajak besar yang jumlahnya 
kurang dari $1 \%$, dimana sisanya adalah Wajib Pajak yang bergerak di bidang UMKM (Rakhmad, 2012 dalam Faudi dan Mangoting, 2013).

Peranan usaha skala kecil dan menengah dalam perekonomian akhir-akhir ini mulai banyak diperhitungkan dalam proses merencanakan suatu kebijakan di bidang perpajakan. Hal tersebut adalah salah satu bagian dari usaha meningkatkan peranan pengusaha dalam proses pengambilan keputusan dan kebijakan dalam lingkungan otoritas pajak. (Prajogo dan Widuri 2013).

Perkembangan UMKM diharapkan kemandiriannya dan menjadi salah satu elemen penting yang mendukung industri-industri besar sehingga keberadaannya sangat dibutuhkan. Upaya secara komprehensif sudah saatnya dilakukan agar sektor usaha kecil menengah mampu tumbuh di kancah perekonomian nasional, bahkan bersaing dalam bisnis global. Institusi pemerintah yang terkait dengan sektor industri yang menjadi bidang kompetensinya semestinya menjadi motivator penggerak usaha kecil menengah, termasuk bagaimana Direktorat Jenderal pajak (DJP) peduli terhadap pemajakan usaha kecil menengah ini. Pajak menjadi bagian yang tidak terpisahkan dari pengembangan usaha kecil menengah secara terintegrasi. Keberpihakan dan kepedulian Direktorat Pajak terhadap usaha kecil menengah seperti pemberian intensif pajak yang sangat penting jika tidak memungkinkan tax holiday (Wibowo, 2004 dalam Hasanah, Khafid dan Anisykurlillah 2014).

Kesadaran kewajibanperpajakan dapat dipengaruhi oleh beberapa faktor diantaranya pengetahuan wajib pajak, pemahaman system self assessment, tingkat penghasilan wajib pajak, dan kemudahan dalam melakukan sistem pembayaran perpajakan.

Berdasarkan paparan diatas, peneliti tertarik untuk meneliti dengan judul "Analisis Faktor-Faktor yang Berpengaruh Terhadap Kesadaran Kewajiban Perpajakan pada Sektor Usaha Kecil dan Menengah (UKM)"

\section{Kajian Pustaka dan Pengembangan Hipotesis}

1. Teori Pembelajaran Sosial

Teori pembelajaran sosial relevan untuk menjelaskan perilaku wajib pajak dalam memenuhi kewajibannya membayar pajak. Seseorang akan taat membayar pajak tepat pada waktunya, jika lewat pengamatan dan pengalaman langsungnya, hasil pungutan pajak itu telah memberikan kontribusi nyata pada pembangunan di wilayahnya. Seseorang juga akan taat pajak apabila telah menaruh perhatian terhadap pelayanan pajak, baik fiskus maupun sistem pelayanan pajaknya. Terkait dengan proses penguatan, dimana individu-individu disediakan rangsangan positif atau ganjaran supaya berperilaku sesuai dengan model. (Jatmiko, 2006 dalam Hasanah, Khafid dan Anisykurlillah, 2014).

\section{Teori Atribusi}

Persepsi seseorang untuk membuat penilaian mengenai orang lain sangat dipengaruhi oleh faktor internal maupun eksternal seseorang. Pada dasarnya, teori atribusi menyatakan bahwa bila individu-individu mengamati perilaku seseorang, mereka mencoba untuk menentukan apakah perilaku itu ditimbulkan karena pengaruh internal atau eksternal (Martinko et al., 2011) dalam (Icuk et al., 2016). Perilaku yang disebabkan secara internal adalah perilaku yang diyakini berada di bawah kendali pribadi individu itu sendiri, sedangkan perilaku yang disebabkan secara eksternal adalah perilaku yang dipengaruhi dari luar, artinya individu akan terpaksa berperilaku karena tuntutan situasi atau lingkungan.

Relevansi teori atribusi dalam penelitian ini yaitu seseorang dalam menentukan perilaku kesadaran dalam memenuhi kewajiban perpajakannya dipengaruhi oleh faktor internal maupun eksternal. Faktor internal yang mempengaruhi kesadaran wajib pajak antara lain pengetahuan wajib pajak tentang peraturan perpajakan, pemahaman system self assessment,dan tingkat penghasilan wajib pajak. Sedangkan faktor eksternal yang mempengaruhi kesadaran wajib pajak yaitu kemudahan dalam melakukan sistem pembayaran perpajakan

Penelitian terdahulu yang berkaitan dengan analisis faktor-faktor yang berpengaruh terhadap kesadaran kewajiban perpajakan pada sektor Usaha Kecil dan Menengah (UKM) yang terdiri dari pengetahuan wajib pajak, pemahaman system self assessment, tingkat penghasilan wajib pajak, dan kemudahan dalam melakukan sistem pembayaran perpajakan telah dilakukan oleh beberapa peneliti seperti yang ditunjukkan berikut ini:

Lubis (2011) tentang analisis faktor-faktor yang mempengaruhi kesadaran dalam melaporkan kewajiban perpajakan pada sektor UKM di kota 
Medan. Variabel independen dalam penelitian ini yaitu pengetahuan wajib pajak, pemahaman wajib pajak tentang peraturan perpajakan, manfaat yang dirasakan wajib pajak, dan sikap optimis wajib pajak terhadap pajak. Populasi dalam penelitian ini adalah pemilik dan atau akuntan usaha Coffeeshop yang berada di daerah kota Medan. Hasil dari penelitian ini menunjukkan bahwa semua faktor yang diuji mempunyai pengaruh terhadap kesadaran wajib pajak. Persamaan regresi ditemukan bahwa pengetahuan tentang peraturan perpajakan, pemahaman terhadap peraturanperpajakan, dan manfaat yang dirasakan mempunyai hubungan positif namun sikapoptimis wajib pajakmempunyai pengaruh yang negatif.

Syahputri et.al (2014) tentang faktor yang mempengaruhi kesadaran wajib pajak PBB (Pajak Bumi dan Bangunan). Penelitian ini bertujuan untuk mengetahui faktor apa yang mempengaruhikesadaran wajib pajak PBB di Kota Medan dengan responden masyarakatyang bertempat tinggal di Perumnas Simalingkar Lingkungan XXII. Faktor tersebutantara lain: sanksi denda, pengetahuan perpajakan, kepercayaan terhadap petugaspajak, penyuluhan, pendidikan dan pendapatan wajib pajak. PBB adalah Pajak Negarayang dikenakan terhadap bumi dan atau bangunan. Metode yang digunakanadalah regresi logistik. Hasil yang diperoleh dari model berturut-turut adalah sanksidenda sebesar 1,3\%; pengetahuan perpajakan sebesar 23,5\%; kepercayaan terhadappetugas pajak sebesar $-20,6 \%$; penyuluhan sebesar -7\%; pendidikan sebesar 13,5\%dan pendapatan sebesar 68,3\%. Hasil dari analisa menunjukkan bahwa pendapatanwajib pajak berpengaruh terhadap kesadaran dalam membayar pajak sebesar $68,3 \%$.

\section{Pengembangan Hipotesis}

1. Pengaruh Pengetahuan Wajib Pajak terhadap Kesadaran Kewajiban Perpajakan

Pengetahuan merupakan salah satu faktor yang berpengaruh yang berasal darifaktor akademik, dimana wajib pajak yang memiliki pengetahuan tentang pajak lewatpendidikan yang lebih tinggi "seharusnya" memiliki kesadaran akan kewajibanperpajakan yang dimiliki lebih baik dibandingkan dengan wajib pajak yang memilikipendidikan lebih rendah. Jadi, pengetahuan wajib pajak mempengaruhi kesadaran wajib pajak dalam kesadaran kewajiban perpajakan pada sektor usaha kecil dan menengah. Berdasarkan hasil tersebut, maka keterkaitan antara pengetahuan wajib pajak terhadap kesadaran kewajiban perpajakan pada sektor usaha kecil dan menengah dapat dirumuskan dengan hipotesis sebagai berikut:

$\mathrm{H}_{1}$ : Pengetahuan wajib pajak berpengaruh terhadap kesadaran kewajibanperpajakan

\section{Pengaruh Pemahaman Sistem Self Assessment terhadap Kesadaran Kewajiban Perpajakan}

Sistem self assessmentmerupakan sistem pemungutan pajak dimana wajib pajak harus menghitung, menyetor, dan melaporkan jumlah pajak yang terhutang. Keuntungan dari sistem self assessment adalah wajib pajak diberikan kepercayaan oleh fiskus untuk menghitung, membayar, dan melaporkan sendiri pajak yang terhutang sesuai dengan peraturan pajak yang berlaku. Jadi, pemahaman wajib pajak mengenai sistem self assessment sangat mempengaruhi kesadaran kewajiban perpajakan dalam mengisi surat pemberitahuan. Karena, apabila wajib pajak tersebut paham akan sistem self assessment, maka tingkat kesadaran wajib pajak dalam memenuhi kewajibannya pun akan tinggi. Berdasarkan hasil tersebut, maka keterkaitan antara pemahaman sistem self assessment terhadap kesadaran kewajiban perpajakan pada sektor usaha kecil dan menengah dapat dirumuskan dengan hipotesis sebagai berikut:

$\mathrm{H}_{2}$ : Pemahaman sistem self assessment berpengaruh terhadap kesadaran kewajibanperpajakan

3. Pengaruh Tingkat Penghasilan Wajib Pajak terhadap Kesadaran Kewajiban Perpajakan

Tingkat penghasilan seseorang berpengaruh terhadap kesadaran dalam melakukan pembayaran perpajakan pada sektor usaha kecil dan menengah. Semakin tinggi tingkat penghasilan seseorang yang diterima, maka tentu semakin tinggi pula pajak yang harus dibayar. Berdasarkan uraian tersebut, maka keterkaitan antara tingkat penghasilan wajib pajak terhadap kesadaran kewajiban perpajakan pada sektor usaha kecil dan menengah dapat dirumuskan dengan hipotesis sebagai berikut:

$\mathrm{H}_{3}$ : Tingkat penghasilan wajib pajakberpengaruh terhadap kesadaran kewajibanperpajakan

4. Pengaruh Kemudahan dalam Melakukan Sistem Pembayaran Perpajakan terhadap Kesadaran Kewajiban Perpajakan 
Pemerintah dan Ditjen Pajak harus senantiasa memberikan inovasi baru mengenai sistem pembayaran pajak yang lebih efektif dan efisien serta memberikan kemudahan bagi wajib pajak dalam menunaikan kewajibannya. Sistem pembayaran yang mudah dilakukan merupakan salah satu fasilitas bagi wajib pajak agar mereka dapat dengan mudah dan nyaman membayarkan kewajibannya. Dengan adanya pelayanan mengenai sistem pembayaran perpajakan ini, pastinya akan mempengaruhi para wajib pajak dalam memenuhi kewajibannya. Jadi, terdapat pengaruh yang positif dan signifikan dengan adanya kemudahan dalam melakukan sistem perpajakan. Sehingga, diperlukan adanya modernisasi dalam melakukan pembayaran pajak, guna meningkatkan kesadaran pembayaran pajak oleh wajib pajak. Berdasarkan uraian tersebut, maka keterkaitan antara kemudahan dalam melakukan sistem pembayaran terhadap kesadaran kewajiban perpajakan pada sektor usaha kecil dan menengah dapat dirumuskan dengan hipotesis sebagai berikut:

$\mathrm{H}_{4}$ : Tingkat kemudahan dalam melakukan sistem pembayaran perpajakan berpengaruh terhadap kesadaran kewajiban perpajakan

\section{Metode Penelitian}

\section{Desain Penelitian}

Desain penelitian ini adalah jenis penelitian kuantitatif dengan melakukan uji hipotesis. Data yang digunakan adalah data primer berupa kuesioner yang diberikan dan diisi oleh responden. Penelitian ini akan mengukur pengaruh pengetahuan wajib pajak, pemahaman system self assessment, tingkat penghasilan wajib pajak, dan kemudahan dalam melakukan sistem pembayaran perpajakanterhadap kesadaran kewajibanperpajakan.

\section{Populasi dan Sampel}

Populasi dalam penelitian ini adalah wajib pajak orang pribadi (WPOP) yang berwirausaha. WPOP yang berwirausaha adalah pengusaha dengan skala usaha mikro, kecil sampai menengah (UMKM). Sampel dalam penelitian ini sebanyak 44 orang responden yang merupakan pemilik usaha kecil dan menengah yang berada di wilayah Jawa Tengah.Teknik pemilihan sampel yang digunakan adalah convenience sampling, yaitu teknik penentuan sampel berdasarkan kesediaan responden.

\section{Pengukuran Variabel}

Variabel dependen dalam penelitian ini adalah kesadaran kewajiban perpajakan. Variabel independen dalam penelitian ini adalah pengetahuan wajib pajak, pemahaman system self assessment, tingkat penghasilan wajib pajak, dan kemudahan dalam melakukan sistem pembayaran perpajakan. Variable-variabel diatas akan diukur dengan menggunakan likert scale yang berdimensi 5 skala. Analisis yang digunakan dalam penelitian ini adalah analisis regresi berganda.

$\mathrm{Y}=\alpha+\beta \_1 \mathrm{PWP}+\beta \_2 \mathrm{PSSA}+\beta \mathrm{TPWP}+\beta \_4 \mathrm{SPP}+\mathrm{e}$

Keterangan:

$\mathrm{Y} \quad=$ Kesadaran Kewajiban Perpajakan

$\alpha \quad=$ Konstanta

$\beta=$ Koefisien masing-masing variabel $\mathrm{X} 1, \mathrm{X} 2$, $\mathrm{X} 3$, dan X4

PWP = Pengetahuan Wajib Pajak

PSSA = Pemahaman System Self Assessment

TPWP = Tingkat Penghasilan Wajib Pajak

SPP = Kemudahan dalam Melakukan Sistem Pembayaran Perpajakan

$\varepsilon \quad=$ Eror

\section{Hasil dan Pembahasan}

Tempat dan waktu penelitian

Penelitian ini dilakukan terhadap industry kecil dan menengah (UKM) yang berada diwilayah Surakarta. Usaha kecil dan menengah yang ikut berpartisipai dalam penelitian ini meliputi usaha kecil dan menengah di bidang elektronik, makanan, pakaian dan bengkel motor. Pengumpulan data dilaksanakan melalui penyebaran kuesioner secara langsung kepada pemilik usaha kecil dan menengah yang berada di wilayah Surakarta.

Penyebaran kuesioner dilaksanakan mulai tanggal 1 oktober - 10 oktober. Peneliti mengambil sampel sebanyak 7 tempat usaha 
kecil dan menengah yangberada di wilayah Surakarta, dengan peta distribusi yang terlihat dalam table 4.1

Table 4.1

Jenis usaha kecil dan menengahh

\begin{tabular}{|l|l|l|l|}
\hline No & Jenis usaha & $\begin{array}{l}\text { Kuesioner } \\
\text { disebar }\end{array}$ & $\begin{array}{l}\text { Kuesioner } \\
\text { dikembalikan }\end{array}$ \\
\hline 1 & Bidang elektronik & 10 & 10 \\
\hline 2 & Makanan & 35 & 25 \\
\hline 3 & Pakaian & 12 & 10 \\
\hline 4 & Bengkel motor & 2 & 2 \\
\hline
\end{tabular}

Karakteristik profil responden

Responden dalam penelitian ini adalah usaha kecil dan menengah yang berada di wilayah Surakarta. Berikut adalah deskripsi mengenai identitas responden penelitian yang terdiri dari umur,jenis kelamin, pendidikan terakhir, lama usaha yang dijalani, dan keuntungan yang diterima sebulan.

a. Deskripsi responden berdasarkan umur, menjelaskan mengenai gambaran responden berdasarkan pembagian umur. Pembagian responden berdasarkan umur terbagi menjadi lima, yaitu kurang dari 30 tahun, 30 tahun sampai dengan 35 tahun, 35 tahun sampai dengan 40 tahun, 40 tahun sampai dengan 45 tahun dan lebih dari 45 tahun. Informasi bahwa mayoritas responden sebanyak 24 responden yang berumur kurang dari 30 tahun, kemudian 10 responden yang berumur 30 sampai 35, 7 responden yang berumur 35 sampai 40, 13 responden yang berumur 40-45, dan 5 responden yang berumur lebih dari 45 .

b. Deskripsi responden berdasarkan jenis kelamin menjelaskan mengenai pembagian responden jenis kelamin, diperoleh informasi bahwa mayoritas responden sekitar 26 berjenis kelamun wanita dan 33 responden berjenis kelamin laki-laki. c. Deskripsi responden berdasarkan pendidikan terakhir, menjelaskan mengenai pembagian responden berdasarkan latar belakang pendidikan terakhir. Pembagian responden berdasarkan latar belakang pendidikan terakhirdibagi menjadi lima, yaitu sekolah dasar, sekolah menengah pertama, sekolah menengah atas, strata satu, dan lainnya seperti D3 atau sekolah mengengah kejuruan. Informasi bahwa mayoritas responden sebanyak 1 responden berpendidikan terakhir sekolah menengah pertama, 28 yang berpendidikan terakhir sekolah menengah atas, 19 yang berpendidikan terakhir strata satu dan 11 yang berpendidikan lainnya.

d. Deskripsi responden berdasarkan lama usaha yang dilakukan, menjelaskan mengenai pembagian responden berdasarkan lama usaha yang dilakukan terbagi menjadi lima yaitu kurang dari 2 tahun, 2 tahun sampai 4 tahun, 4 sampai 6 tahun, 6 sampai 8 tahun, dan lebih dari 8 tahun. Informasi bahwa mayoritas responden sebanyak 16 yang kurang dari 2 tahun, 11 responden yang mempunyai lama usaha 2 sampai 4 tahun, 9 responden yang mempunyai lama usaha 4 sampai 6 tahun, 5 responden yang mempunyai lama usaha 6 sampai 8 tahun, dan 14 responden yang mempunyai lama usaha lebih dari 8 tahun.

e. Deskripsi responden berdasarkan keuntungan usaha setiap bulan, menjelaskan mengenai kisaran keuntungan usaha yang diterima usaha kecil dan menengah setiap bulan. Dari lima puluh Sembilan usaha kecil dan menengah yang diambil datanya, rata-rata usaha kecil dan menengah mendapatkan keuntungan usaha sekitar kurang dari Rp 5.000.000. Informasi bahwa mayoritas responden sebanyak 27 responden yang mempunyai keuntungan usaha kurang dari 
Rp5.000.000 , kemudian 20 responden yang mempunyai keuntungan Rp5.000.000Rp10.000.000, 9 responden yang mempunyai keuntungan Rp10.000.000-Rp15.000.000, 1 responden yang mempunyai keuntungan Rp15.000.000-Rp20.000.000, dan 2 responden yang mempunyai keuntungan Rp20.000.000.

Hasil uji asumsi klasik

a. Hasil uji multikolinearitas

Tabel dibawah ini menjelaskan mengenai hasil uji multikolinearitas, dimana tidak terdapat problem multiko pada model persamaan regresi dan dapat digunakan dalam penelitian ini

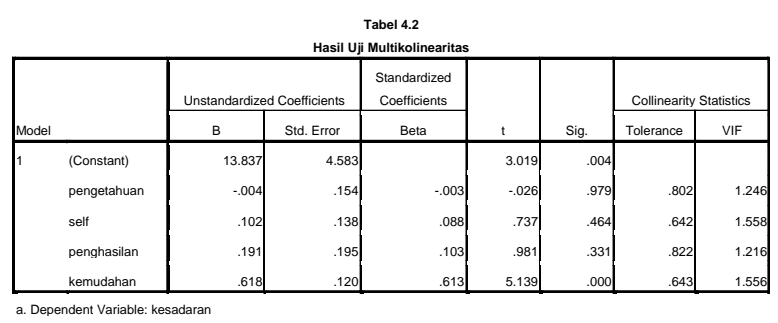

Berdasarkan table 4.2 terlihat bahwa nilai tolerance mendekati angka 1 dan nilai variance inflation factor (VIF) disekitar angka 1 untuk setiap variabel, yang ditunjukkan dengan nilai tolerance 0,$802 ; 0,642 ; 0,822 ; 0,643$, serta VIF sebesar 1,246 untuk variabel pengetahuan wajib pajak; 1,558 untuk variabel pemahaman self assessment; 1,216 untuk variabel tingkat penghasilan wajib pajak dan 1,556 untuk variabel kemudahan dalam melakukan sistem pembayaran.

\section{b. Hasil Uji Normalitas}

gambar dibawah ini menjelaskan mengenai hasil uji normalitas, dimana gambar tersebut memperlihatkan penyebaran data yang berada disekitar garis diagonal dan mengikuti arah garis diagonal.

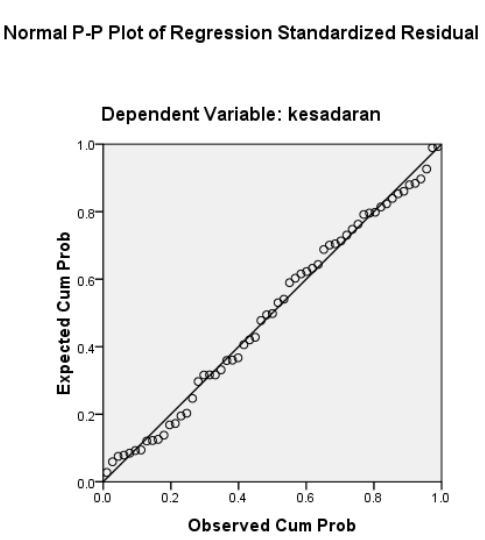

c. Hasil Uji Heteroskedastisitas

Gambar dibawah ini menjelaskan mengenai ada tidaknya heteroskedastisitas dilakukan dengan melihat ada tidaknya pola tertentu pada grafik scatterplot antara SRESID dan ZPRED, yang diperlihatkan pada gambar dbawah ini:

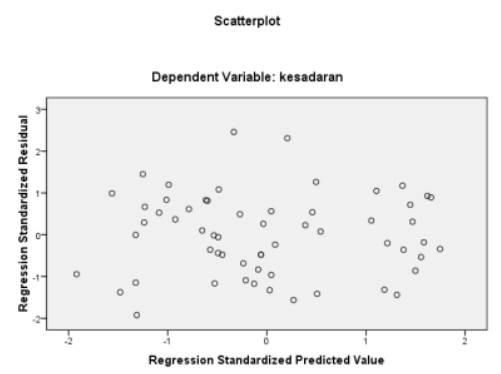

Berdasarkan gambar diatas grafik scatterplot menunjukkan bahwa data tersebar di atas dan dibawah angka 0 (nol) pada sumbu $Y$ dan tidak terdapat suatu pola yang jelas pada penyebaran data tersebut. Hal ini berarti tidak terjadi heteroskedastisitas pada model persamaan regresi, sehingga model regresi layak digunkan untuk memprediksi kesadaran kewajiban perpajakan pada sector usaha kecil dan menengah berdasarkan variabel yang mempengaruhinya, yaitu pengetahuan wajib pajak, pemahamana sistem self assessment, tingkat penghasilan wajib pajak, dan tingkat kemudahan dalam melakukan sistem pembayaran perpajakan. 
d. Hasil uji hipotesis

Pengujian hipotesis dilakukan dengan menggunakan model analisis regresi berganda yaitu:

Uji Koefisien Determinasi

Table dibawah ini menjelaskan mengenai besarnya nilai persentasi keterkaitan faktor-faktor yang mempengaruhi kesadaran kewajiban perpajakan pada sector usaha kecil dan menengah

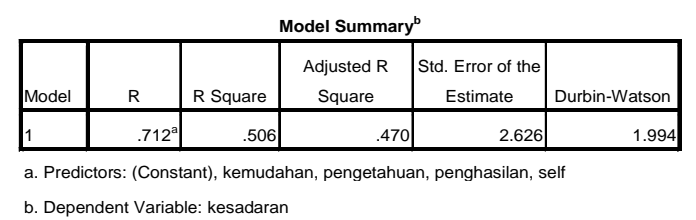

Tabel diatas menunjukkan bahwa nilai $\mathrm{R}$ sebesar 0,712 atau $71,2 \%$. Hal ini berarti bahwa hubungan atau korelasi antara faktorfaktor yang mempengaruhi kesadaran kewajiban perpajakan pada sector usaha kecil dan menengah. Nilai Adjustes R Square sebesar 0,506 atau 50,6\% menunjukkan bahwa variabel kesadaran kewajiban perpajakan pada sector usaha kecil dan menengah dapat dijelaskan oleh pengetahuan wajib pajak, pemahaman sistem self assessment, tingkat penghasilan wajib pajak, dan tingkat kemudahan dalam melakukan sistem pembayaran perpajakan sebesar $50,6 \%$, sedangkan sisanya $50,4 \%$ dijelaskan oleh faktor-faktor lain yang tidak disertakan dalam penelitian ini.

\section{Hasil Uji t statistic}

Uji t statistic digunakan untuk mengetahui pengaruh masing-masing variabel indpenden secara individual terhadap variabel indepanden yang diuji pada tingkat signifikasi 0,05 . Hasil uji statistic t dapat dilihat pada table 4.13, jika nilai probability t lebih kecil dari 0,05 maka Ha diterima dan menolak H0 sedangkan jika nilai probability $\mathrm{t}$ lebih besar dari 0,05 maka H0 diterima dan menolak Ha.

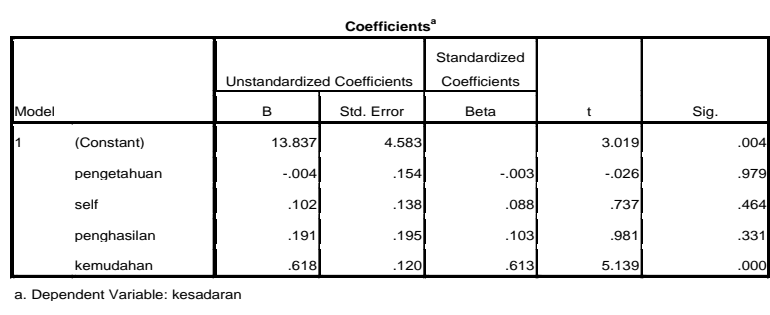

Hasil uji hipotesis 1 :

Pengaruh Pengetahuan Wajib Pajak terhadap Kesadaran Kewajiban Perpajakan pada Sektor Usaha Kecil dan Menengah

Hasil uji hipotesis 1 dapat dilihat dari table 4.13, variabel pengetahuan wajib pajak mempunyai tingkat signifikasi sebesar 0,979. Hal ini berarti menolak Ha1 sehingga variabel pengetahan wajib pajak tidak berpengaruh secara signifikan terhadap kesadaran kewajiban perpajakan pada sector usaha kecil dan menengah karena tingkat signifikasi yang memiliki variabel pengetahuan wajib pajak lebih besar dari 0,05 .

Hasil Uji Hipotesis 2:

Pengaruh Pemahamana Sistem Self Assessment Terhadap Kesadaran Kewajiban Perpajakan Pada Sektor Usaha Kecil dan Menengah Hasil uji hipotesis 2 dapat dilihat pada table 4.13 variabel pemahaman sistem self assessment mempunyai tingkat signifikasi sebesar 0,464. Hasil ini berarti menolak Ha2 sehingga variabel pemahaman sistem self assessment tidak berpengaruh secara signifikan terhadap kesadaran kewajiban perpajakan pada sector usaha kecil dan menengah karena tingkat signifikasi yang dimiliki variabel pemahaman sistem self assessment lebih besar dari 0,05

Hasil Uji Hipotesis 3:

Pengaruh Tingkat Penghasilan Wajib Pajak Terhadap Kesadaran Kewajiban Perpajakan Pada Sektor Usaha Kecil dan Menengah.

Hasil uji hipotesis 3 dapat dilihat pada table 4.13, variabel tingkat penghasilan wajib pajak mempunyai tingkat signifikasi sebesar 0,331 . Hal ini berartu menolak Ha3 sehingga variabel 
tingkat penghasilan wajib pajak tidak berpengaruh secara signifikan terhadap kesadaran kewajiban perpajakn pada sector usaha kecil dan menengah karena tingkat signifikasi yang dimiliki variabel tingkat penghasilan wajib pajak lebih besar dari 0,05 .

Hasil Uji Hipotesis 4:

Pengaruh Kemudahan Dalam Melakukan Sistem Pembayaran Perpajakan Terhadap Kesadaran Kewajiban Perpajakan Pada Sektor Usaha Kecil dan Menengah

Hasil uji hipotesis 4 dapat dilihat pada table 4.13, variabel pengaruh kemudahan dalam melakukan sistem pembayaran perpajakan mempunyai tingkat signifikasi sebesar 0,000. $\mathrm{Hal}$ ini berarti menerima Ha4 sehingga variabel pengaruh kemudahan dalam melakukan sistem pembayaran perpajakan berpengaruh secara signifikan terhadap kesadaran kewajiban perpajan pada sector usaha kecil dan menengah karena tingkat signifikasi yang dimiliki variabel tingkat penghasilan wajib pajak lebih kecil dari 0,05

Berdasarkan table 4.13, maka diperoleh persamaan regresi adalah sebagai berikut:

$\mathrm{Y}=13,837+0,004 \mathrm{X} 1+0,102 \mathrm{X} 2+0,191 \mathrm{X} 3+0,618$ $\mathrm{X} 4+\mathrm{e}$

Maka apabila setiap peningkatan pengetahuan wajib pajak (X1) satu satuan maka kesadaran kewajiban perpajakan pada sector usaha kecil dan menengah akan meningkat sebesar 0,004 per tahun, kemudia setiap peningkatan pemahaman sistem self assessment (X2) satu satuan maka kesadaran kewajiban perpajaan pada sector usaha kecil dan menengah akan meningkat sebesar 0,102 per tahun. Setiap peningkatan tingkat penghasilan wajib pajak (X3) satu satuan maka kesadaran kewajiban perpajakan pada sector usaha kecil dan menengah akan meningkat sebesar 0,191 per tahun, kemudian setiap peningkatan tingkat kemudahan dalam melakukan sistem pembayaran perpajkan (X4) satu satuan maka kesadaran kewajiban perpajkan pada sector kecil dan menengah akan meningkat sebesar 0,618

Hasil Uji Simultan (Uji F)

Uji simultan digunakan untuk mengetahui pengaruh semua variabel independen yang dimasukkan dalam model regresi secara bersama-sama terhadap variabel dependen yang diuji pada tingkat signifikasi 0,05 . Hasil uji statistic $\mathrm{F}$ dapat dilihat pada table 4.14,jika nilai probabilitas lebih kecil dari 0,05 maka Ha diterima dan menolak H0 sedangkan jika nilai probabilitas lebih besar dari 0,05 maka H0 diterima dan menolak Ha

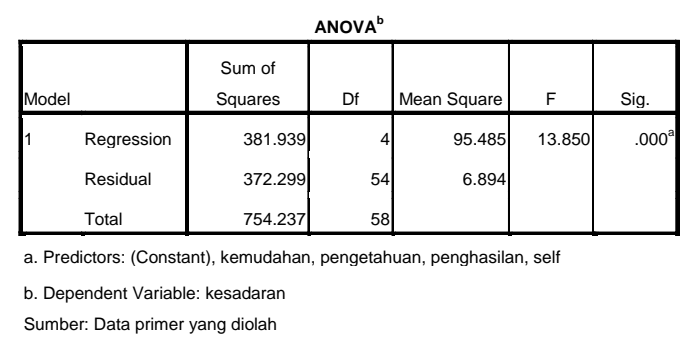

Pengaruh Pengetahuan Wajib Pajak, Pemahaman Sistem Self Assessment, Tingkat Penghasilan Wajib Pajak, Kemudahan Dalam Melakukan Sistem Pembayaran Perpajakan Terhadap Kesadaran Kewajiban Perpajakan Pada Sektor Usaha Kecil dan Menengah

Hasil uji hipotesis dapat dilihat pada table nilai $\mathrm{F}$ diperoleh sebesar 13,850 dengan tingkat signifikasi 0,000 . Karena tingkat signifikasi lebih kecil dari 0,05 maka Ha5 diterima, sehingga variabel pengetahuan wajib pajak, variabel pemahaman sistem self assessment, variabel tingkat penghasilan wajib pajak, variabel kemudahan dalam melakukan sistem pembayaran perpajan berpengaruh secara simultan dan signifikan terhadap kesadaran kewajiban perpajan pada sector usaha kecil dan menengah. 
Pembahasan

\section{Pengaruh Pengaruh Wajib Pajak}

Hasil uji hipotesis berdasarkan 4.13 menunjukkan bahwa tingkat signifikan variabel pengetahuan wajib pajak sebesar 0,979 lebih besar dari 0,05 , sehingga pengetahuan wajib pajak tidak berpengaruh terhadap kesadaran kewajiban perpajakan pada sector usaha kecil dan menengah. Dengan demikian, semakin tingkat pengetahuan wajib pajak tentang perpajakan maka belum tentu semakin tinggi tingkat kesadaran kewajiban perpajakn, sedngkan semakin rendah pengetahuan wajib pajak maka semakin rendah tingkat kesadaran kewajiban perpajakannya.

\section{Pengaruh Pemahaman Sistem Self} Assessment

Hasil uji hipotesis berdasarkan table 4.13 menunjukkan bahwa tingkat signifikasi variabel pemahaman sistem self assessment tidak berpengaruh terhadap kesadaran kewajiban perpajkan pada sector usaha kecil dan menengah. Hal ini dapat disebabkan karena, walaupun wajib pajak paham tentang sistem self assessment belum tentu berpengaruh terhadap tingkat kesadaran kewajiban perpajakan, dikarenakan semakin paham seseorang tentang sistem self assessment akan berusaha untuk membayar pajak tidak sesuai dengan jumlah pajak yang terhutangnya.hasil penelitian ini konsisten dengan penelitian yang dilakukan oleh Maria Ulfa Malik (2007) yang menyatakan bahwa pemahaman sistem self assessment berpengaruh terhadap kewajiban perpajakan.

\section{Pengaruh Tingkat Penghasilan Wajib Pajak}

Hasil uji hipotesis berdasarkan table 4.13 menunjukkan bahwa tingkat signifikasi varibel tingkat penghailan wajib pajak sebesar 0,331 lebih besar dari 0,05, sehingga tingkat penghasilan wajib pajak tidak berpengaruh terhadap kesadaran kewajiban perpajakan pada sector usaha kecil dan menengah. Hal ini dapat disebabkan karena semakin tinggi tingkat penghasilan wajib pajak belum tentu tingkat kesadaran dalam membayar pajak semakin tinggi, dikarenakan semakin tinggi penghasilan seseorang tentu saja semakin tinggi pula jumlah pajak yang harus dibayar. Hasil penelitian ini konsisten dengan penelitian yang dilakukan oleh Yusrinillah (2006), yang menyatakan bahwa tingkat penghasilan wajib pajak tidak terlalu berpengaruh terhadap motivasi memenuhi kewajiban pajak

4. Pengaruh kemudahan dalam melakukan sistem pembayaran perpajan

Hasil uji hipotesis berdasarkan menunjukkan bahwa tingkat signifikasi variabel kemudahan dalam melakukan sistem pembayaran perpajakan sebesar 0,000 lebih besar dari 0,05 sehigga kemudahan dalam melakkan sistem pembayaran perpajkan berpengaruh terhadap kesadaran kewajiban perpajakan sector usaha kecil dan menengah. Hubungan anatara pengaruh kemudahan dalam melaukan sistem pembayraan perpajakan dengan kesadaran dalam membayar pajak adalah positif. Dikarenakan semakin mudah sistem pembayaran perpajkan, maka semain tinggi kesadaran wajib pajak dalam melakukan pembayaran pajak. Hasil penelitian ini konsisten dengan penelitian yang dilakukan oleh Leli Agestin (2007),yang menyatakan bahwa modernisasi kantor pelayanan pajak dapat meningkatkan kepatuhan wajib pajak.

\section{Simpulan}

Penelitian ini bertujuan ini untuk mengetahui pengetahuan wajib pajak, pemahaman wajib pajak, pemahaman sistem self assessment, tingkat penghasilan wajib 
pajak, kemudahan dalam melaukan sistem pembayaran perpajakan terhadap kesadaran kewajiban perpajakan pada sector usaha kecil dan menengah. Responden penelitian ini berjumlah 59 orang pemilik usaha kecil dan menengah yang terletak di Surakarta. Berdasarkan dari data yang telah dikumpulkan dan pengujian yang telah dilakukan terhadap permasalahan dengan menggunakan model regresi berganda, maka dapat diambil kesimpulan sebagai berikut:

1. Pengetahuan wajib pajak tidak berpengaruh terhadap kesadaran kewajiban perpajakan pada sector usaha kecil dan menengah. Hasil penelitian ini mendukung dengan penelitian sebelumnya.

2. Pemahaman sistem self assessment tidak berpengaruh secara signifikan terhadap kesadaran kewajiban perpajakan pada sector usaha kecil dan menenga. Hasil penelitian ini tidak mendukung dengan penelitian yang dilakukan oleh Maria Ulfa Malik (2007) yang menyatakan bahwa pemahaman sistem self assessment berpengaruh terhadap kewajiban perpajakan.

3. Tingkat penghasilan wajib pajak tidak berpengaruh secara signifikan terhadap kesadaran kewajiban perpajakan pada sector usaha kecil dan menengah. Hasil penelitian ini mendukung dengan penelitian sebelumnya yang dilakukan oleh Yusrinillah (2006) yang menyatakan bahwa tingkat penghasilan wajib pajak tidak terlalu berpengaruh terhadap motivasi memenuhi kewajiban pajak.

4. Kemudahan dalam melakukan sistem pembayaran perpajakan berpengaruh secara signifikan terhadap kesadaran kewajiban perpajakan pada sector usaha kecil dan menengah. Hasil penelitian ini mendukung dengan penelitian sebelumnya oleh Leli Angesti (2007) yang menyatakan bahwa modernisasi kantor pelayanan pajak dapat meningkatkan kepatuhan wajib pajak.

\section{Referensi}

[1] Aliyah, Siti. 2014. "Makna Pajak dan Implikasinya dalam Bingkai Perspektif Wajib Pajak UMKM (Studi Interpretatif pada Wajib Pajak UMKM di Kabupaten Jepara)". Jurnal Dinamika Ekonomi dan Bisnis, Vol. 11 No.1, Maret 2014.

[2] Astari, Elvina Apriani. 2016. "Pengaruh Tingkat Pendidikan Dan Pemahaman Wajib Pajak Terhadap Kemauan Membayar Pajak Melalui Kesadaran Wajib Pajak Orang Pribadi Memiliki Npwp Sebagai Variabel Intervening (Studi Kasus Pada Masyarakat Di Kota Samarinda, Kalimantan Timur)". Skripsi UMY: Yogyakarta

[3] Faudi dan Mangoting.2013. "Pengaruh Kualitas Pelayanan Petugas Pajak, Sanksi Perpajakan dan Biaya Kepatuhan Pajak Terhadap Kepatuhan Wajib Pajak UMKM".TAX \& ACCOUNTING REVIEW, VOL.1, NO.1, 2013.

[4] Hardiningsih, Pancawati. 2011. "Faktor-faktor yang Memengaruhi Kemauan Membayar Pajak". Jurnal Dinamika Keuangan dan Perbankan, Vol.3 No.1, 2011 hal 126-142

[5] Hasanah, Khafid dan Anisykurlillah.2014. "Kepatuhan Wajib Pajak UMKM di Kabupaten Jepara". AAJ volume 3 Nomer 1 2014ISSN 2252-6765.

[6] Lovihan, Siska. 2014. "Pengaruh Kesadaran Membayar Pajak, Pengetahuan dan Pemahaman Peraturan Perpajakan, dan Kualitas Layanan Terhadap Kemauan Membayar Pajak Wajib Pajak Orang Pribadi di Kota Tomohon". Jurnal Riset Akuntansi dan Auditing, Vol.5 No.1, 2014 hal 44-59

[7] Nugroho, R Adi., 2012."Faktor-Faktor yang Mempengaruhi Kemauan untuk Membayar Pajak dengan Kesadaran membayar Pajak Sebagai Variabel Intervening", Agustus, hal 50-51, 
Skripsi, Fakultas Ekonomika dan Bisnis, Universitas Dipenogoro, Semarang.

[8] Pusparini, Agustina Dwi.2016. "Pengaruh Pemahaman Wajib Pajak dan Pelaksanaan Sanksi Pajak Terhadap Kesadaran Wajib Pajak Orang Pribadi”. Skripsi UI: Jakarta.

[9] Prajogo dan widuri.2013. "Pengaruh tingkat pemahaman peraturan pajak wajib pajak, kualitas pelayanan petugas pajak, dan persepsi atas sanksi perpajakan terhadap kepatuhan wajib pajak umkm di wilayah sidoarjo". tax \& accounting review vol. 3. no.2 2013.

[10] Priantara, Diaz dan Supriyadi, Bambang. 2011. "Faktor-faktor yang Memengaruhi Pengusaha Kecil dan Mikro Mendaftar Menjadi Wajib Pajak Orang Pribadi”. Jurnal Akuntansi dan Keuangan Vol. 13, No.2 hal 98-108

[11] Rahmatika, Muffi. 2010. “Analisis Faktor-Faktor yang Berpengaruh Terhadap Kesadaran Kewajiban Perpajakan pada Sektor Usaha Kecil dan Menengah (UKM)". Skripsi UIN: Jakarta.

[12] Rizal, Muhammad Lubis. 2011. "Analisis FaktorFaktor yang Memengaruhi Kesadaran dalam Melaporkan Kewajiban Perpajakan pada Sektor UKM di Kota Medan". Jurnal Riset Akuntansi dan Bisnis Vol. 11, No.2 hal 171-190

[13] Syahputri M Sari., dkk., 2014. "Faktor-Faktor yang Mempengaruhi Kesadaran Wajib Pajak PBB (Pajak Bumi dan Bangunan)", Saintia Matematika, Vol. 2 No. 3, hal. 7. 